\title{
Obituary Wylie W Vale
}

Neuropsychopharmacology (2012) 37, 2886; doi: 10.1038/npp.2012.165

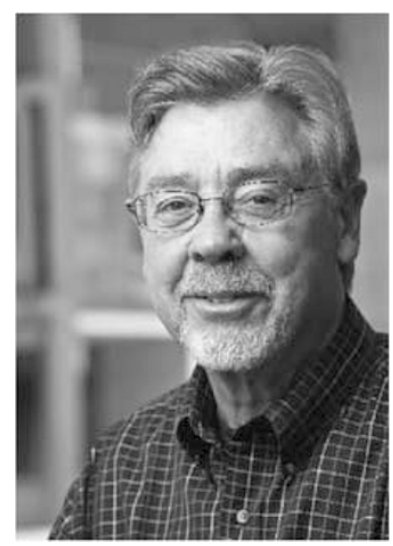

Wylie Vale, a member of the ACNP and a giant in the field of neuroendocrinology and molecular neurobiology, died unexpectedly on 3 January 2012 at his vacation home in Hawaii. His storied career was launched in his hometown of Houston, graduating from Rice University in 1964 and then joining the laboratory of eventual Nobel Laureate Roger Guillemin for his PhD degree in Physiology and Biochemistry at the Baylor College of Medicine. He remained in this $\mathrm{lab}$ as a post-doctoral fellow, and then relocated with Guillemin and his entire team to the Salk Institute in 1970. In 1978, he left the Guillemin laboratory and established The Clayton Foundation Laboratories for Peptide Biology, a position he held for almost 34 years. He was promoted to the rank of Professor in 1980 and named the Helen McLoraine Chair and Professor of Molecular Neurobiology in 2003. Wylie's scientific productivity could only be described as prodigious. He published consistently in the very best journals in our field-Science, Nature, PNAS, J Biol Chem, J Neurosci, and Neuropsychopharmacology-in total more than 1000 publications, the vast majority original research reports. His scientific achievements include the elucidation of the structure of corticotropin-releasing factor (CRF) and the related urocortins, whereas in the Guillemin lab, he contributed to the discovery of somatostatin and thyrotropin-releasing hormone. What was most remarkable about Wylie was his ability to have great vision and constantly reinvent himself, for example, from a classic physiologist to a molecular neurobiologist. He epitomized the now infamous quote of Wayne Gretzy, often cited by Steve Jobs, 'I skate to where the puck is going to be, not where it has been'. This personified Wylie Vale. Thus, he not only discovered CRF, but led the field in studies of its receptors, their distribution and signal transduction, its remarkable role in regulating autonomic, immune, neuroendocrine, and behavioral responses to stress, and in development of CRF receptor antagonists. Space constraints preclude my discussion of seminal findings he and his colleagues contributed to reproductive physiology, diabetes, and cancer research. For all of these accomplishments, he was recognized by his peers with election to the National Academy of Sciences and to the Institute of Medicine. He received innumerable awards, including those from the Endocrine Society, the Karolinska Institute, and others. Most important to emphasize, however, is the man Wylie was. One measure of a man is, of course, their relationship with those around him, their students, fellows, and colleagues. Wylie was worshiped by these folks and he delighted in their success-there is simply too long a list of these individuals for me to provide here. I personally know of dozens at the Salk and elsewhere. Wyle was inquisitive, hardworking, broad minded, a lover of wine, funny, mischievous, and most of all, ready for adventure. He loved life as much as anyone I have known. He never said no to a flyfishing journey, a passion he came to in the last decade of his life. He never missed an ACNP meeting, and particularly enjoyed the 2011 meeting in Hawaii. At a dinner there approximately 2 weeks before his untimely death, he spoke of his daughters, and their husbands, his new granddaughter (with pictures on his iPhone), and of course, his beloved wife Betty. To paraphrase Einstein, 'Our death is not an end if we can live on in our children (and students) and the younger generation. For they are us, our bodies are only wilted leaves on the tree of life'. He was much beloved by his peers and family, and will be sorely missed by all.

Charles B Nemeroff ${ }^{1}$

${ }^{1}$ Department of Psychiatry and Behavioral Sciences, University of Miami Miller School of Medicine, Miami, FL, USA

E-mail: cnemeroff@med.miami.edu 